\title{
Attainment of Sustainable Business Productivity through Economic Governance and Management in Nigeria
}

\author{
Kingsley Nwagu*
}

Ph.D. Candidate at the Department of Management, School of Research, Texila American University, Guyana

DOI: $10.36348 /$ sjef.2020.v04i12.009 $\quad$ | Received: 13.12 .2020 | Accepted: 24.12 .2020 | Published: 29.12 .2020

*Corresponding author: Kingsley Nwagu

\section{Abstract}

This study was carried out to ascertain if economic governance and management brings about the attainment of sustainable business productivity in Nigeria. In this study, economic governance and management was utilized as the explained variable, while the various indicator variables of economic governance and management such as: Macroeconomic Policies, Transparent, predictable and credible state economic policies, Sound Public Finance Management, Corruption and Money Laundering and Integration Policies were used as the explanatory variables. The research design used in this study was the cross-sectional survey design, associated with the deductive approach used for descriptive research purpose, which was used to model the impact of economic governance and management on sustainable business productivity in Nigeria. The findings elicited from this study revealed that economic governance and management was significant and played a key role in allowing businesses in Nigeria attain sustainable productivity within the scope of this study.

Keywords: Economic governance and management, Macro-economic Policies, Transparent, predictable and credible state economic policies, Sound Public Finance Management, Corruption and Money Laundering, sustainable business productivity and Integration Policies.

Copyright (C) 2020 The Author(s): This is an open-access article distributed under the terms of the Creative Commons Attribution 4.0 International License (CC BY-NC 4.0) which permits unrestricted use, distribution, and reproduction in any medium for non-commercial use provided the original author and source are credited.

\section{INTRODUCTION}

Overtime, and particularly after political independence in 1960, the development of the Nigerian economy has been guided by several structures beginning with the First National Development Plan (1962 - 68), heralding large-scale public sector intervention in the economy. The public sector engaged in import-substitution activities and direct production of goods and services that ought to be the concern of the private sector [1].

This was premised on the notion that market failures could be addressed by public sector intervention in economic activity in order to enhance living standard of the citizens. However, the approach tended to create inefficiency in resource allocation and slow pace of development, in spite of the fact that the country had enormous endowment of human, material and natural resources. The Asian countries that were at the same or lower level of development with Nigeria in the early 1960s and had limited resources have achieved phenomenal growth and development that seem to suggest poor governance of the Nigerian economy over the years. The public sector intervention in economic activity through public enterprises has been a disaster as it has been characterized by conflicting objectives, poor management of resources, persistent losses in public enterprises, political interferences, etc [2]. On the other hand, the private sector has also failed to live up to expectations, as shown by failures in the banking and financial services as well as manufacturing sectors. Adedeji [3] observed that the private sector in Nigeria became infested with non-productive entrepreneurs and dealers in foreign currencies, which was inimical to good performance of the sector. The poor performance of the public and private sector clearly became a source of concern to stakeholders in the economy, particularly multilateral institutions and donor agencies. A consensus gradually emerged that the roles of the public and private sectors needed to be re-defined by reducing the size of the public sector, which would ultimately free economic resources for more rapid economic growth. This led to a framework that emphasized private sector-led growth strategy, while the role of public sector shifts from owner of productive enterprises to that of policy maker and regulator. The public sector, therefore, only needs to encourage private sector development by providing an enabling environment that consists of elements such as 
Kingsley Nwagu., Saudi J Econ Fin, Dec, 2020; 4(12): 609-614

macroeconomic stability, elimination of barriers to market forces, security of lives and property, efficient infrastructure, among others [4]. Thus, for the private sector to perform efficiently as the engine of growth in the economy, the public sector must be seen not to be competing in the market [5]. This is the underlying philosophy of the economic governance structure in Nigeria today, and indeed most developing countries of the world, in contrast to the position of massive public sector intervention in the 1960s and 1970s.

Economic Governance and Management is the broad national economic policy framework, the institutions, processes and practices in place that are aimed at facilitating, supporting or otherwise promoting an economic climate that encourages growth, poverty reduction and the general welfare of the citizens. Good economic governance including transparency in financial management is all essential prerequisites for promoting economic growth and reducing poverty. Therefore, the establishment and consolidation of strong economies that can produce the wealth needed for investment in infrastructure and profit-making enterprises is fundamental. It is also equally important that such economies are organized and managed so as to ensure that the benefits of their expansion are broadly distributed across the population on a sustainable basis, taking into account the needs of both society and the environment. To achieve these outcomes, appropriate governance interventions are necessary, including the creation of an economic policy environment that encourages growth, investment and regional integration, and whose ultimate object is the transformation of the lives of all the citizens for the better. It is multi-pronged and focuses on the actions, policies and programmes that the relevant economic authorities (in particular, the state, regulatory agencies, and to a lesser extent businesses and business organizations) are adopting and implementing in managing the economy [6].

This is done with an understanding that a dynamic economy is not sufficient in itself; that it must be complemented by appropriate systems and institutions that ensure the smooth functioning of markets, the combating of corruption, the regulation of capital flows and the equitable distribution of wealth to meet the needs of the people. In addition, the full and meaningful involvement of the citizens in the conceptualization, formulation and implementation of these policies is a central principle that promotes shared ownership of the economy. This in turn is a major factor in ensuring success and growth. It looks at the state of countries' economies, beginning with the overall policy trajectory or vision, and the principles that underlie it.

The objectives of the Africa Peer Review Mechanism (APRM) under this Theme: Design and implement economic policies for sustainable development, encourage ownership and participation of

key stakeholders in policy formulation and
implementation, promote sound public finance management, Fight corruption and money laundering, Accelerate and deepen regional integration in the monetary, trade and investment domain, Develop and implement trade and investment policies for promoting economic growth [7].

Sustainable Development means that economic growth and expanded opportunities to create wealth, generate employment and raise living standards are achieved without excessive costs to the environment, to the economic fundamentals or to the population, and that this growth can continue in the long term. It is therefore important that economic policies are formulated and implemented in this light. The management of public finances has to be accountable, transparent and efficient in order to achieve the desired effect on both the economy and public's trust in the institutions of state [8].

Corruption erodes the effectiveness of policies and programmes, as well as the trust of the public in institutions of governance. It further constitutes a drain on the meagre resources of the state and the overall economy. Therefore, it is important to eradicate corrupt practices in the management and administration of public resources and institutions. While corruption is a Cross-Cutting Issue throughout this Questionnaire, the purpose of this section is to focus on corruption in public procurement, whereby both public and private actors involved in the procurement process may be tempted to divert public funds, goods or services for their personal use.

Money laundering can be defined as a process where proceeds of a criminal activity are disguised to conceal their origin. By so doing, criminals introduce their dirty money in the financial sector, which enables them to avoid prosecution, conviction and confiscation of their criminal proceeds [9].

The harnessing and strengthening of intercountry economic complementarities is recognized as one of the pillars of economic growth. Therefore, it is important that African countries design and implement policies that facilitate the deepening and acceleration of regional economic integration [10].

Trade and investment are recognized as key drivers of economic growth. It is therefore important that African countries develop and implement policies that encourage, protect and stimulate investment (local and foreign) and trade in order to accelerate economic growth.

The objective of this study is to empirically investigate if economic governance and management brings about the attainment of sustainable business productivity in Nigeria. 
Kingsley Nwagu., Saudi J Econ Fin, Dec, 2020; 4(12): 609-614

\section{METHODOLOGY}

The study adopts a survey research design method. The study used multiple regression approach to express the relationship among the variables. Lucas [11], opined that a multiple regression approach is a form of research method that involves collecting data on two or more variables independent and computing them to find the relationship or association that exists between the variables and a dependable variable. The major purposes of multiple regression design are to explore causal relationships between variables and to predict scores on one variable from research participant's scores on other variables. A highly structured questionnaire was used as instrument for data collection. The study geographical area was Nigeria; however, selected states from each six geo-political zones were sampled for data collection. Data collected for the study were presented using statistical tools, while multiple regression analysis using ANOVA was adopted to analyze the variables in the models under study.

\section{Model Specification}

The model for the study is therefore stated thus in functional form:

$\mathrm{EGM}=\mathrm{f}(\mathrm{MEP}, \mathrm{TEP}, \mathrm{SFM}, \mathrm{CML}, \mathrm{IPC}) \ldots \ldots \ldots \ldots \ldots \ldots 1$

$\mathrm{EGM}=\boldsymbol{\alpha}+\beta_{1} \mathrm{MEP}+\beta_{2} \mathrm{TEP}+\beta_{3} \mathrm{SFM}+\beta_{4} \mathrm{CML}+\beta_{5} \mathrm{IPC} \ldots .2$

To account for other indices not included in the model we introduce the stochastic variable.

$\mathrm{EGM}=\boldsymbol{\alpha}+\beta_{1} \mathrm{MEP}+\beta_{2} \mathrm{TEP}+\beta_{3} \mathrm{SFM}+\beta_{4} \mathrm{CML}+$

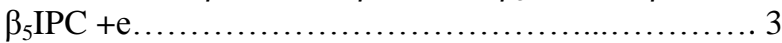

Where:

$\mathrm{EGM}=$ Economic Governance and

Management

MEP = Macro-economic Policies

TEP = Transparent, predictable and credible state economic policies

$\mathrm{SFM}=$ Sound Public Finance Management

$\mathrm{CML}=$ Corruption and Money Laundering

IPC $=$ Integration Policies

$\alpha=$ slope, $\beta_{1}-\beta_{5}=$ Coefficients and $\mathrm{e}=$ stochastic variable, which shows the influence of other indices affecting the dependent variable.

RESULT AND FINDINGS

Table-1: Model Summary

\begin{tabular}{|l|l|l|l|l|}
\hline Model & R & R Square & Adjusted R Square & Std. Error of the Estimate \\
\hline 1 & $.921^{\mathrm{a}}$ & .848 & .846 & .37835 \\
\hline
\end{tabular}

Source: SPSS 20.0 output

Table-2: ANOVA ${ }^{\text {a }}$

\begin{tabular}{|l|l|l|l|l|l|l|}
\hline \multicolumn{2}{|l|}{ Model } & Sum of Squares & Df & Mean Square & F & Sig. \\
\hline \multirow{3}{*}{1} & Regression & 382.933 & 5 & 63.822 & 445.852 & $.000^{\mathrm{b}}$ \\
\cline { 2 - 7 } & Residual & 68.567 & 18991 & .143 & & \\
\cline { 2 - 7 } & Total & 451.500 & 18996 & & & \\
\hline
\end{tabular}

Source: SPSS 20.0 output

Table-3: Coefficients ${ }^{\mathrm{a}}$

\begin{tabular}{|c|c|c|c|c|c|c|}
\hline \multirow{2}{*}{\multicolumn{2}{|c|}{ Model }} & \multicolumn{2}{|c|}{ Unstandardized Coefficients } & \multirow{2}{*}{$\begin{array}{l}\text { Standardized Coefficients } \\
\text { Beta }\end{array}$} & \multirow[t]{2}{*}{$\mathbf{T}$} & \multirow[t]{2}{*}{ Sig. } \\
\hline & & B & Std. Error & & & \\
\hline \multirow[t]{6}{*}{1} & (Constant) & 1.322 & .400 & & 3.309 & .001 \\
\hline & MEP & .182 & .041 & .171 & 4.424 & .000 \\
\hline & TEP & .488 & .037 & .362 & 13.195 & .000 \\
\hline & SFM & .281 & .046 & .219 & 6.103 & .000 \\
\hline & CML & -.034 & .046 & -.031 & -.745 & .457 \\
\hline & IPC & -.634 & .027 & -.669 & -23.675 & .000 \\
\hline
\end{tabular}

Source: SPSS 20.0 output

The result of analysis shown in Tables 1,2 and 3 above presents the result of the relationship between Economic Governance and Management (EGM) and various independent variables.
The result of the regression estimates from Table-3 above indicates that there is a positive relationship between Economic Governance and Management (EGM) and Macro-economic Policies (MEP). This is evidenced by coefficient value of 0.182 . 
Kingsley Nwagu., Saudi J Econ Fin, Dec, 2020; 4(12): 609-614

Statistically, the Sig. value of 0.000 is lower than the acceptable significance value of 0.05 . This means that Macro-economic Policies significantly relate to Economic Governance and Management. Transparent, Predictable and Credible State Economic Policies (TEP) has coefficient value of 0.488 . Statistically, the Sig. value of 0.000 is lower than the acceptable significance value of 0.05 . This means that TEP is significantly related to EGM. Also Sound Public Finance Management (SFM) was observed to be positively related to Economic Governance and Management (EGM) with a coefficient value of 0.281 and a Sig. value of 0.000 . Corruption and money laundering (CML) from the result has a negative and insignificant effect on Economic Governance and Management (EGM). This evidenced by a coefficient and Sig. value of -0.034 and 0.457 respectively. Finally, Integration Policies (IPC) has a coefficient value of -0.634 and a Sig. value of 0.000 , indicating that IPC has a negative but significant effect on EGM.

\section{SUMMARY}

Corruption is a major element of the poor governance and instability in most developing and transition economies. The exact cost of corruption may not be known and probably will never be known simply because it is a secret crime which goes unreported, but its implications for economic growth and development are not in doubt. It hinders proper resource management and undermines efforts to facilitate growth and reduce poverty by obstructing sound and sustainable private sector growth [12]. Corruption undermines the rule of law and the legitimacy of a state, and destroys the integrity of national institutions on which economic development depends [12]. It also accelerates crime, hurts investment, stalls economic growth, bleeds the national budget, burdens the poor disproportionately, and diverts scarce resources from basic human needs. Indeed, from the perspectives of several authors, corruption is associated with slow economic growth, reduced investment, lower public revenue, feeble property and contract rights, ineffective institutions, limited social interaction, weak rule of law, poor economic competitiveness, deep ethnic divisions and conflicts, social and political tension, low participation in politics, weak protection of civil liberties, low educational attainment, closed economic and political systems [13]. Corruption impacts negatively on economic growth through a wide range of channels [13]: growth of small and medium-sized businesses, which are the engine of job creation and economic growth. The negative impact of corruption falls mostly on the poor who are hardest hit when there is an economic decline. The poor are the most reliant on public services and are the least capable of paying the extra cost associated with corruption. Again, when public officials embezzle state funds, which are meant to provide services, the poor suffer more. Over the years, corruption has persisted in Africa as indicated by Transparency International corruption perception index
(CPI), but the degree varies across countries, and by implication the quality of governance has been under severe threat of deterioration. The level of corruption is high in virtually all the countries, which probably explains the low growth rates, particularly in Nigeria, Kenya, South Africa, Zimbabwe, Gabon and Cote d'Ivoire.

From the results elicited from the analysis in Table-3, its obvious that MEP, TEP and SFM all recorded positive impact on EGM, while CML and IPC both recorded negative impact on EGM. It is important to note that all the variables barring CML were statistically significant in the model in investigating if economic governance and management brings about the attainment of sustainable business productivity in Nigeria.

\section{CONCLUSION}

The objective of this study is to empirically investigate if economic governance and management brings about the attainment of sustainable business productivity in Nigeria. It is important to note that economic governance and management plays an important role in allowing for the attainment of sustainable business productivity in the Nigerian business clime. This assertion is supported by the degree or level of significance of the various indicators of economic governance and management while analyzing their impact on economic governance and management. The results elicited from data analysis revealed that economic governance and management was significant and played a key role in allowing businesses in Nigeria attain sustainable productivity within the scope of this study. It is on the strength of these findings that we submit that the attainment of sustainable business productivity in Nigeria can be said to be a function of economic governance and management.

\section{RECOMMENDATIONS}

Based on results of data analysis conducted in this study, the following recommendations are made;

1. The government and other regulatory monetary authorities in Nigeria should harness macroeconomic (fiscal and monetary) policies towards the attainment of sustainable business productivity in Nigeria.

2. Also, it is important to point out that it is the duty of economic policy makers in Nigeria to formulate and implement transparent, predictable and credible state economic policies which will enhance the attainment of sustainable business productivity in Nigeria.

3. In the same vein, policy makers in Nigeria should ensure Sound Public Finance Management of scarce resources of the government in order to provide an enabling environment where business could thrive. 
Kingsley Nwagu., Saudi J Econ Fin, Dec, 2020; 4(12): 609-614

4. The government in conjunction with anti-graft agencies in Nigeria should apprehend and prosecute public office holders who engage in corruption and looting of public funds.

5. Finally, government should formulate Integration Policies that will enable business achieve sustainable business productivity in Nigeria.

\section{APPENDIX}

Economic Governance and Management (EGM)

\section{Indicators}

- Macro-economic policies (MEP)

- Transparent, predictable and credible state economic policies (TEP)

- $\quad$ Sound public finance management (SFM)

- Corruption and money laundering (CML)

- Integration policies (money, trade, investment among participating countries) (IPC).

\section{Model}

$\mathrm{EGM}=\mathrm{f}(\mathrm{MEP}, \mathrm{TEP}, \mathrm{SFM}, \mathrm{CML}, \mathrm{IPC})$

\begin{tabular}{|c|c|c|c|c|c|c|}
\hline & STATEMENTS & SA & $\mathbf{A}$ & $\mathbf{U}$ & D & SD \\
\hline & Macro-Economic Policies (MEP) & & & & & \\
\hline 1. & $\begin{array}{l}\text { The current policies on fiscal, monetary, trade and exchange rates in the country tends } \\
\text { to stabilize the economy }\end{array}$ & & & & & \\
\hline 2. & $\begin{array}{l}\text { Nigeria's structural economic reforms have entailed liberalization, deregulation and } \\
\text { privatization of key sectors of the economy }\end{array}$ & & & & & \\
\hline \multirow[t]{2}{*}{3.} & $\begin{array}{l}\text { Nigeria remains vulnerable to shocks as a result of high dependence on the oil sector } \\
\text { and the resultant lack of diversification in economic activities }\end{array}$ & & & & & \\
\hline & Transparent, predictable and credible state economic policies (TEP) & & & & & \\
\hline 1. & $\begin{array}{l}\text { Nigeria, in spite of its elaborate federal administrative units, is not yet practicing } \\
\text { proper federalism }\end{array}$ & & & & & \\
\hline 2. & $\begin{array}{l}\text { Many citizens of the country are reluctant to pay taxes as a result of perceived failure } \\
\text { of national, state and local government to provide basic amenities }\end{array}$ & & & & & \\
\hline \multirow[t]{2}{*}{3.} & $\begin{array}{l}\text { There is lack of transparency about the quantum of mineral resources extracted in the } \\
\text { country hence, the uncertainty of such expected revenue }\end{array}$ & & & & & \\
\hline & Sound public finance management (SFM) & & & & & \\
\hline 1. & $\begin{array}{l}\text { The federal government has instituted reforms aimed at strengthening public } \\
\text { expenditure management and overall budget expenditure }\end{array}$ & & & & & \\
\hline 2. & $\begin{array}{l}\text { The national assembly activities recently has reawakened sound public finance } \\
\text { management }\end{array}$ & & & & & \\
\hline \multirow[t]{2}{*}{3.} & $\begin{array}{l}\text { Inefficiency of revenue collection system in state and local government level has in } \\
\text { over-dependency in federal allocation }\end{array}$ & & & & & \\
\hline & Corruption and Money Laundering (CML) & & & & & \\
\hline 1. & $\begin{array}{l}\text { The Nigerian society does not stigmatize corruption and in fact tends to accept it as a } \\
\text { norm in most transactions }\end{array}$ & & & & & \\
\hline 2. & Corruption remains a societal disease in Nigeria which manifest in different ways & & & & & \\
\hline \multirow[t]{2}{*}{3.} & Nigeria demonstrates seriousness in combatting corruption and money laundering & & & & & \\
\hline & $\begin{array}{l}\text { Integration policies (money, trade, investment among participating countries) } \\
\text { (IPC) }\end{array}$ & & & & & \\
\hline 1. & $\begin{array}{l}\text { Nigerian membership of a number of regional groups is an evidence strong support } \\
\text { for regional integration }\end{array}$ & & & & & \\
\hline 2. & $\begin{array}{l}\text { Nigeria's regional integration policy and practices continue to be mainly driven by } \\
\text { the public sector with very little or no inducement for the private sector }\end{array}$ & & & & & \\
\hline 3. & $\begin{array}{l}\text { The free movement of people and goods within west Africa has had a positive impact } \\
\text { on trade volume in the region }\end{array}$ & & & & & \\
\hline
\end{tabular}

\section{REFERENCES}

1. Ndulu, B. J. (1993). The role of state and the market in reformed economic management in subSaharan Africa. In: Redefining the Role of the State and the Market in Development Process. Nigerian Journal of Social Development. 1(1):3649.

2. Obadan, M. I. (1998). The State, Leadership, Governance and Economic Development,
Presidential Address at the Annual Conference of Nigerian Economic Society, Kano, July 22-24.

3. Adedeji, A. (1996). Address Presented at the Opening of the $8^{\text {th }}$ Banking Conference of Maryland Finance Company Ltd, Lagos, September 26.

4. Obadan, M. I. (1997). The free enterprise system and the development of African economies. Nigerian Economic and Financial Review. 2(December): 1-20. 
Kingsley Nwagu., Saudi J Econ Fin, Dec, 2020; 4(12): 609-614

5. Hero, A. O., Fessler, J. A., \& Usman, M. (1996). Exploring estimator bias-variance tradeoffs using the uniform CR bound. IEEE Transactions on Signal Processing, 44(8), 2026-2041.

6. Aron, J. (2000). Growth and institutions: a review of evidence. The World Bank Research Observer. 15(1):99-135.

7. Edo, S. E. (2002). The relevance of dutch-disease model in the emerging economy of Nigeria.

8. Brunette, A. (1997). Political variables in crosscountry analysis. Journal of Economic Survey. 11(2):163-190.

9. Barro, R. J. (1991). Economic growth in a crosssection of countries. Quarterly Journal of Economics. 106(2):407-443.
10. Ezekwesili, O. (2002). Making transparency, accountability imperative: the due process. Certified National Accountant, OctoberDecember. Journal of Social and Management Sciences. 30(1):337-349.

11. Lucas, R. E. (1988). On the mechanics of economic development. Journal of Monetary Economics, 22(January): 3-42.

12. African Development Bank. (2000). African Development Report. Cambridge University Press, New York. African Development Bank. 2001. Fostering Good Governance in Africa, In: African Development Report

13. Obadan, M. I. (2003). National Development Planning and Budgeting in Nigeria, Some Pertinent Issues, Broadway Press Ltd, Lagos. 